\title{
RADIATION SAFETY OF BULGARIA IN THE CONTEMPORARY INTERNATIONAL SITUATION
}

\author{
Nikolay DOLCHINKOV, PhD \\ Vasil Levski Military University, Veliko Tarnovo, Bulgaria \\ e-mail: n_dolchinkov@abv.bg
}

\begin{abstract}
It is known that everything on our planet is subjected to constant exposure from the natural and anthropogenic, earth and space SIR, and is situated in conditions created by natural and technical radioactive Backlight. The ionizing radiations accompany planet life in its different manifestations of all phases of the evolution. The National Automated System for continuous monitoring of the radiation background has 26 local monitoring stations (LMS) covering the whole country, with greater density around NPP 'Kozloduy'. Radiometric measurements in real conditions, sampling, and analysis are carried out by the Executive Environment Agency (EEA) at the MoEW and radiological control laboratories. A special place in radiation safety is taken by timely detection of radioactive waste and materials that appear in one way or another in the environment.
\end{abstract}

Keywords: radiation safety, background, nuclear, monitoring, ionizing radiation

\section{Introduction}

The discovery of radioactivity was one of the greatest discoveries of 'humankind. Just a few weeks after the discovery of X-rays (in 1896), the French physicist Henri Becquerel, while studying phosphorescent properties of various substances, began 
experiencing with potassium uranisulfat ${ }^{1}$. The experience consisted in the fact that after exposure to daylight, the mineral, well wrapped in light-tight black paper, was checked after a while to see if it phosphorescented. The silhouette of the mineral was outlined under the influence of strong radiation of great penetrating power on photo emulsions ${ }^{2}$. That is how the existence of the newly called uranium rays was discovered by Becquerel, called the radioactivity phenomenon by Marie Curie.

This discovery was quickly adapted into medicine and the first X-ray machines were created that led to a revolution in medicine. Subsequently, advanced and modernized X-ray machines of the latest generation repeatedly raised the precision of diagnostic activity and helped save hundreds of lives. At the same time, it was found that radioactive rays are a major polluter of the environment with an extremely strong impact on the life and physiological activity of organisms ranging from incentives to killing. It is known that everything on our planet is subjected to constant exposure from the natural and anthropogenic, earth and space SIR, and is situated in conditions created by natural and technical radioactive Backlight. The ionizing radiations accompany planet life in its different manifestations of all phases of the evolution ${ }^{3}$.

Because of its geopolitical location, the nuclear power plants in Bulgaria and in a country that is close to us can have a great impact on the surrounding natural radioactive background ${ }^{4}$. Optimizing and managing existing radiation monitoring systems will lead to increased nuclear security in Bulgaria and adequate measures and decision making to improve the protection of the population from radiation exposure as a result of changes in the natural radioactive background.

The aim of this study is to analyse the factors influencing the natural radioactive background and the measures to be taken for its upgrading, to optimize the monitoring and publicity systems for the radioactive pollution of the environment and to identify the possibilities for increasing its effectiveness. To accomplish this goal, the following research tasks need to be addressed:

1 Radioecology, Vasilev D., Titus Consult, Sofia 2005, p 24.

2 Characteristics of radiation, Dolchinkov N. T., N. B. Nichev, Revista academiei fortelor terestre „Nicolae Bãlcescu”, Sibiu,Rumania, no.2(82)/2016, p. 184.

3 Radiation ecology. Pivovarova Yu, V. Mikhalev. Moscow. Academy, 2004, p. 43.

4 Ordinance on basic safety standards, BSRP-2004, Council of Ministers, Sofia, 2004, p. 16. 
1. Evaluation and analysis of the existing systems for monitoring the radiation background in the Republic of Bulgaria (RB);

2. Investigation of the meteorological factors influencing the change of the natural radiation background. Examination of existing and projected nuclear facilities in the area that impacts on the Republic of Bulgaria. Analysis and evaluation of these in the context of the current international political environment;

3. Exploration and optimization of the applied management procedures and determination of a model for the choice of control options.

During the years after World War II, due to the development of atomic manufacture and the notably heightened testing of nuclear weapons, issues developed related to the active contamination of the planet. After an atomic explosion in the air, the products of nuclear fission pollute the atmosphere, water, plants, food and more. The importance of the issues arising from radioactive contamination have interested many scientists who have explored different sides of the pollution with radionuclids and developed new science disciplines.

Environmental pollution by radioactive substances began with the creation of the atomic bomb and the emergence of the nuclear industry. Harmful effects of radiation on living organisms and humans were not known to begin with. At the dawn of the nuclear age, society did not have the information needed for this activity because of the secrecy of the nuclear production and it was not possible to assess accurately the impact and extent of this pollution. Biotechnologies have been developed in which specific algae are extracted and uranium is concentrated in the biomass and, thus, water is purified.

The first serious pollution caused by human activity was in Japan from 5 to 6 August 1945. Over the Japanese cities of Hiroshima and Nagasaki without special military necessity, American dropped the first atomic bombs in history. The era of the nuclear race began, which included the former Soviet Union, and the number of nuclear countries today is more than 20 .

Of course, environmental pollution and soil pollution by radioactive substances is enhanced with the appearance of a nuclear industry. At first, the negative effects of radiation on the environment and man were unknown, due to insufficient theoretical and field studies and the secrecy of the proceedings it was not possible 
to estimate accurately the amount of such pollution, ecological and social damage caused by it.

For a long time it was believed that it would not be very dangerous. Later it was found that the various stages of production of uranium fuel (open or closed mines, hydro production and concentration of uranium purification, enrichment, etc.) could bring about "contamination" of environmental radionuclide uranium, especially radon (Rn-222). Waste from the hydrometallurgical plants was initially discharged without adequate treatment into the nearest rivers and polluted agricultural fields and plants. Later it was recommended that in uranium contaminated water special algae could be grown that can extract and concentrate uranium and purify water, and indirectly protect from contamination.

Of course, of the largest scale and of the highest intensity was the radioactive contamination of the environment and soil following the accident in Trimaylaylan, USA 1976; Chernobyl, Ukraine 26.04.1986; Fukushima, Japan March 2011 and other nuclear accidents and catastrophes.

Local pollution was seen in Spain in 1966 as a result of the mid-air collision of aircraft carrying nuclear weapons. Radioactive substances from a nuclear device that didn't explode were scattered over an area of several thousand hectares. 990 tons of soil was excavated and put in tombs for radioactive substances in South Carolina, USA. This case shows that, with contemporary armaments, despite the high degree of security, the risk of nuclear contamination of vast areas actually exists, even in peacetime.

Under national legislation, the Ministry of Environment and Water is the competent authority which carries out specialised monitoring of radiation in the environment. The radiological monitoring system of the Ministry is carried out under a programme approved by the Minister of Environment and Water. The programme was developed at the Executive Environment Agency (EEA) and is updated annually. It includes a network of observation points, respectively frequency and a range of observed indicators of environmental components: soil, air and water. The programme is part of the National Automated Environmental Monitoring System (NEMS).

Radiometric measurementsin real conditions, sampling and analysis are performed by the EEA and radiological control laboratories in the Regional Inspectorates of 
Environment (Regional Inspectorate) inBurgas, Varna, Vratsa, Montana, Pleven, Plovdiv and Stara Zagora.

\section{Monitoring of natural radioactivity}

\section{Gamma background}

Observations on the state of the radiation background in Bulgaria are carried out in parallel in two ways:

1. By the National Automated System for continuous monitoring of the radiation background, by 26 local monitoring stations (LMS) covering the whole country, with greater density around Kozloduy NPP. For operational action in the event of an accident this can include a mobile monitoring station. The automated system establishes an occasional raising of the natural gamma background in the country and provides early information about neighboring countries in the event of a radiological emergency.The LMS perform additional measurements of basic meteorological parameters to interpret data ${ }^{5}$.

The National Automated System provides exact-time data for the the State Agency "Fire safety and protection of the population" at the Interior Ministry and the Committee for use of nuclear energy for peaceful purposes. There are departmental systems for radiation monitoring at the Ministry, Ministry of Health, National Centre for Meteorology and Hydrology at the Bulgarian Academy of Sciences, including 42 laboratories for qualitative and quantitative spectrometric analysis.

2. By discreet measurements of the gamma radiation background in the permanent observation points at Burgas, Varna, Vratsa, Montana, Pleven, Plovdiv, Stara Zagora and Sofia, triplicate daily measurements are taken. The results obtained in both ways show that the radiation background in 2015 is typical for the respective points and the particular weather conditions.

5 National report on the status and protection of the environment in Bulgaria in 2014 of the EEA, Council of Ministers, Sofia, 2014, p. 28. 


\section{Atmospheric radioactivity}

Studies of atmospheric radioactivity are carried out by stationary stations with automatic sampling in the Ministry's systems located in Sofia, Burgas, Vratsa, Varna and Montana. Portable equipment in Plovdiv, Stara Zagora and Pleven takes additional measurements to check possible cross-border contaminaion.

Annual data from the monitoring of atmospheric radioactivity is distinguished by background concentrations of technogenic Cs-137 $(<3 \mathrm{mBq} / \mathrm{m} 3)$ and cosmogeneous Be-7 (from 0.7 to $\left.15.7 \mathrm{mBq} / \mathrm{m}^{3}\right)^{6}$.

\section{Development of the National Automated System for continuous monitoring of gamma radiation in Bulgaria}

Under current national legislation, the Ministry of Environment and Water (MoEW) is the competent authority which carries out specialised monitoring of the radiation situation of the environment in Bulgaria ${ }^{7}$. Radiometric measurements in real conditions, sampling and analysis is carried out by the Executive Environment Agency (EEA) at the MoEW and radiological control laboratories in the Regional Inspectorates of Environment and Water (RIEW) in Burgas, Varna, Vratsa, Montana, Pleven, Plovdiv and St. Zagora ${ }^{8}$.

The late disclosure of the Chernobyl accident and its aftermath led to the need for continuous monitoring of background radiation and the exchange of data between countries both in Europe and worldwide. Establishment of a National Automated System for Continuous Monitoring of the Gamma Radiation Background in Bulgaria (BULRaMo) was started in 1992 by the German company ENVINET GmbH. In 1997, it was commissioned to implement the Ordinance on the construction, operation and development of the National Automated

6 Bulletin gamma background in Bulgaria the NRA, Council of Ministers, Sofia, 2015, p. 36.

7 Annual Report NRA 2014, Council of Ministers, Sofia, 2014, p. 3.

8 Quarterly bulletin on the state of the environment for the period October to December 2016 of the EEA, Council of Ministers, Sofia, 2017, p. 12-15. 
System for continuous monitoring of the radiation background in the Republic of Bulgaria, Decree № 434 / 19.11.1997. The office responsible for construction and maintenance of the system is MoEW through the EEA, with funds under the PHARE 9 .

The main purpose of this national radiation monitoring system operating in real time is:

- Continuous monitoring and surveillance of the level of gamma radiation throughout the country and preserving the received information in a national database.

- Early warning of a rise in the level of gamma radiation as a result of an accident with radioactive pollution of the environment or conflict with the use of nuclear weapons.

- Submission of operational information to the relevant government authorities responsible for the radiation situation in Bulgaria.

- Submission of operational information to the European System of Radiological Data Exchange (EURDEP) and the Agency for the use of nuclear energy for peaceful purposes (IAEA).

Analysis of the existence and design of facilities located close to Bulgaria or the planned construction of such to optimise the layout of LMS takes place in the cross-border areas. This includes Cernavoda NPP in Romania about $30 \mathrm{~km}$ from Silistra, the military base, Deveselu, about $40 \mathrm{~km}$ from Svishtov also in Romania and the NPP south of Resovo 20 kilometres from the border with Turkey. In the construction of Belene, NPP will need to release more LMS in its 30 kilometre area in order to enhance public safety and related infrastructure.

The wind plays a major role in the spread of radioactive particles, so exploring its direction and speed over the last five years, I consider it necessary to launch new 3 LMS or redirect some of those available.

A special place in radiation safety is taken by the timely detection of radioactive waste and materials in one way or another in the environment. Upon acceptance of

9 Structure and Management of the National Automated System for Permanent Control of the Radiation Gamma Background in Bulgaria, Dolchinkov N. T., N. B. Nichev. Land Forces Academy Review NR. 2 (86) / 2017 - C. 117. 
scrap iron, steel, copper or other metal waste, processing plants inspect incoming raw materials with special dosimeters. In the presence of a radioactive source, the resulting feedstock is thoroughly checked and only then is the agent of change to natural events submitted for processing. All such cases appear on EEA's pages.

\section{Other channels for the control of radioactive background}

Transport and storage of radioactive materials that pose a danger to people and the environment is carried out by specialised companies and under strict rules. This is controlled by the Nuclear Regulatory Agency (NRA) and is subject to the Ordinance on the transportation of hazardous materials.

The state border of the Republic of Bulgaria is guarded by Border Police, who are part of the structure of the Ministry. The control of incoming and outgoing passengers and cargo is observed by the Customs Agency at the Ministry of Finance to the Treasury at certain border crossing points (BCPs) on terrestrial, aquatic and aerial borders. There, all vehicles, cargo and passengers are subjected to dose monitoring in order to detect the presence of radioactive materials. Controls are performed to verify the existence of documents issued by competent state authorities to legalise the transfer of nuclear material or radioactive sources, as well as the compliance of these documents in terms of transmission.

Availability of sources of ionizing radiation is set at checkpoints based on the following basic steps:

- detection of the source of ionizing radiation;

- confirmation (verification) of the availability of source;

- locating the source;

- recognition (identification) of the radioactive isotope and prompt notification of the NRA and the Ministry. The implementation of these steps is carried out using portable, hand-portable, mobile and stationary equipment at the radiation control checkpoint. 
Hand-portable equipment can be:

- a personal radiation detector (pager) that is used to ensure radiation safety for employees, giving them information about radiation levels and helping them to stay a safe distance from the radiation source;

- a radiation dosimeter, which is designed to confirm the presence and to locate a radioactive source as part of a secondary inspection;

- a device for recognition of a radioactive isotope (URRI) which performs detection by analysing the characteristic peaks in the energy range of the radiation and comparing it with a pre-loaded library of spectra.

Mobile equipment consists of a mobile detection system in a van employed in joint police operations in the border area. The fixed equipment consists of radiation portal monitors (MPN), which are mounted checkpoints to detect the presence of radioactive material through built-in design detectors for gamma rays and neutrons.

When submitting an alarm signal from a portal, the monitors apply two kinds of procedures. Firstly, the so-called standard operating procedure that includes implementation of major steps to decide whether the object should be omitted or triggers the second procedure, namely the procedure for emergency response in the detection of illegal transport of radioactive materials in border checkpoint areas of Bulgaria. This procedure is part of the National Emergency Plan for emergency response.

People crossing the state border checkpoint in random unregulated places can cause serious problems. These are the so-called migrants, most of whom are not fleeing from war, but are economic migrants or even potential terrorists. The million human flow, moving from Africa and Asia to the heart of Europe, is a serious challenge for the leaders of the united Europe. They are representatives of other nationalities, cultures and religions that are not typical for Europeans and on this basis leads to serious contradictions of religious, cultural and other bases. Very often these conflicts escalate to unmanageable collisions and interference from relevant government authorities.

The main channel of migrants went around Bulgaria and passed through other countries such as Greece, Macedonia, Serbia, Hungary and others. After the closure of the borders of some countries the flow decreased, but potential 
migrants are located in Bulgaria's neighbouring countries Turkey and Greece, and they can once again take the road to Germany and other countries of central Europe. Although we are not attractive as a destination for these settlers, we are not insured by the pressure to be a transit corridor ${ }^{10}$. Recently, the media have published more frequent reports that show the smooth passage of the BulgarianTurkish border, the presence of a large contingent of migrants and refugees in the city centres and their capture on the Bulgarian-Serbian border.

Among the people fleeing from war, some are members of the "Islamic state" other terrorist or extremist organisations. Such trained agents have been found already by a number of specialised organisations in some European countries. They can be carrying weapons, ammunition and other explosives, as well as women and children. There is no guarantee for Bulgaria or other European countries that they are not carrying radioactive materials or nuclear fuel. An omission of both our national and European security is that it does not check for the presence of both weapons and radioactive materials. This would reduce the likelihood of terrorist actions and operations and possible casualties.

\section{Conclusions}

A well developed and organised system for the control of Gamma-background atmospheric radioactivity, radiation capable of affecting uncultivated soil and radiological characteristics of surface water from rivers and reservoirs in the Republic of Bulgaria exists to inform the population of radiation accidents, and needs some attention to function better.

Gamma radiation, atmospheric radioactivity, radiation capable of affecting uncultivated soil and the radiological characteristics of surface water from rivers and reservoirs in Bulgaria is part of a country's typical background values. It is

10 Historical overview and analysis of national automated system for continuous mon itoring of gamma radiation, Dolchinkov N.T. VIII научно-практического семинара Економічна безпека держави і науково-технологічні аспекти ï забезпечення, Кіів, 2016. 
necessary to improve the reporting of radiation pollution of the Danube and the Black Sea.

There is a well-functioning system of transport and storage of radioactive materials and modern control of border crossings, internal customs stations and factories for the processing of scrap metal. Bulgaria has insufficient control over the availability and illegal transportation of radioactive materials and migrants.

\section{Bibliography}

Annual Report NRA, 2014, Council of Ministers, Sofia, 2014.

Bulletin gamma background in Bulgaria the NRA, Council of Ministers, Sofia, 2015.

Dolchinkov N.T. Historical overview and analysis of national automated system for continuous mon itoring of gamma radiation, VIII научно-практического семинара Економічна безпека Аержави і науково-технологічні аспекти їі забезпечення, Кіів, 2016.

Dolchinkov N. T., N. B. Nichev, Characteristics of radiation, Revista academiei fortelor terestre „Nicolae Bãlcescu”, Sibiu,Rumania, no.2(82)/2016.

Dolchinkov N. T., N. B. Nichev. Structure and Management of the National Automated System for Permanent Control of the Radiation Gamma Background in Bulgaria, Land Forces Academy Review NR. 2 (86) / 2017.

National report on the status and protection of the environment in Bulgaria in 2014 of the EEA, Council of Ministers, Sofia, 2016.

Pivovarova Yu, V. Mikhalev, Radiation ecology, Moscow, Academy, 2004.

Ordinance on basic safety standards, BSRP-2004, SG. 73, 2004, Council of Ministers, Sofia, 2004.

Quarterly bulletin on the state of the environment for the period July-September 2016 of the EEA, Council of Ministers, Sofia, 2016.

Quarterly bulletin on the state of the environment for the period October to December 2016 of the EEA,; Council of Ministers, Sofia, 2017.

Vasilev D., Radioecology, Titus Consult, Sofia 2005.

Бюлетин за гама-бона в Р България на АЯР, Министерски съвет, София, 2015.

Годишен доклад на АЯР за 2013 г, Министерски съвет, София, 2014.

Годишен доклад на АЯР за 2014 г, Министерски съвет, София, 2015.

Закон за безопасно използване на ядрената енергия, Министерски съвет, София, 2017.

Закон за опазване на околната среда, Министерски съвет, София, 2017. 
Наредба за изграждане, експлоатация и развитие на Националната автоматизирана система за непреквснат контрол на радиационния гамабон в Р България, Министерски съвет, София, 1997.

Наредба за норми за целите на радиационната защита и безопасност при ликвидиране на последствията от урановата промишленост в Р България, Министерски съвет, София, 2011.

Наредба за Основни норми за радиационна защита, Министерски съвет, София, 2012.

Наредба за планиране и готовност за действия при радиачионна авария, Министерски съвет, София, 2008.

Техническо описание на системата за мониторинг, АЕЦ Козмодуй, 2012. 